\title{
https://doi.org/10.46813/2021-134-135 \\ SEPARATION OF ELECTROENCEPHALOGRAM \\ LOW-FREQUENCY COMPONENTS ON THE BASIS \\ OF THE STOCHASTIC RESONANCE EFFECT
}

\author{
O.I. Kharchenko ${ }^{1}$, Yu.F. Lonin ${ }^{1}$, L.P. Zabrodina ${ }^{2}$, V.M. Kartashov ${ }^{3}$ \\ ${ }^{1}$ National Science Center "Kharkov Institute of Physics and Technology”, Kharkiv, Ukraine; \\ ${ }^{2}$ State Institution "Institute of Neurology, Psychiatry \\ and Narcology of the National Academy of Medical Sciences of Ukraine”, Kharkiv, Ukraine; \\ ${ }^{3}$ Kharkiv National University of Radioelectronics, Kharkiv, Ukraine \\ E-mail: oksana.kharchenko@nure.ua; lonin@kipt.kharkov.ua; inpn_zabrodina@ukr.net; \\ volodymyr.kartashov@nure.ua
}

The paper describes the method for electroencephalogram (EEG) analysis based on the stochastic resonance (SR) effect. The numerical computation has provided the separation of low frequency components that fall within the $\delta$-rhythm band. This is currently central in the neuropathology diagnostics, because the presence of low frequencies in the EEG is abnormal and bears witness to the disease. For verification, the data obtained with the use of the SR effect have been compared with the computations based on the autocorrelation function (ACF) processing. The comparison has shown their good agreement.

PACS: 05.45

\section{INTRODUCTION}

The present-day disease diagnostics is to a large extent based on the data of numerous instrumental methods of examination. In neurology, extensive use is made of the EEG-based diagnostics [1,2].

Electroencephalography is the encephaloscopy diagnostic technique, which is based on registration of brain electric potentials. Between two brain regions, and also, between the brain regions and somatic tissues, distant from the brain, there arise varying potential differences, the registration and analysis of which is the main objec- tive of electroencephalography. The EEG presents a complex oscillatory process, which can be registered with electrode arrangement on the brain or the scalp surface. The EEG is the result of electric summation and filtration of elementary processes taking place in brain neurons.

In the contemporary neurology the EEGs are classified according to some basebands designated as "rhythms" [1, 2]. The basic EEG rhythms are listed in Table.

Classification of EEG rhythms [2]

\begin{tabular}{|c|c|c|}
\hline \multicolumn{3}{|c|}{ EEG rhythms of a wakeful adult } \\
\hline Rhythm & Frequency, Hz & Amplitude, $\mu \mathrm{V}$ \\
\hline$\alpha$ & $8 \ldots 13$ & Up to 100 \\
\hline$\beta$ & $14 \ldots 40$ & $\begin{array}{c}\text { Up to } 15 \\
\text { normally } 3 \ldots 7\end{array}$ \\
\hline \multicolumn{2}{|c|}{ Types of activities pathological for the wakeful adult } \\
\hline$\delta$ & $0.5 \ldots 3$ & \begin{tabular}{c} 
Exceeds $40 \mu \mathrm{V}, \begin{array}{c}\text { amounting at some pathological states } \\
\text { to } 300 \mu \mathrm{V} \text { and more }\end{array}$ \\
\hline
\end{tabular} \\
\hline
\end{tabular}

It can be seen from Table that of particular interest is the separation of low-frequency components, namely, the frequencies lying in the regions of $\delta$ - and $\theta$-rhythms, since they are pathological for the wakeful adult. The lower is their frequency and the higher is the amplitude, the more clearly defined is the pathological process $[1,2]$.

\section{METHOD OF EEG RHYTHM SEPARATION BASED ON THE SR EFFECT}

Since the mathematical model of EEG is still nonexistent at present, and its creating appears very problematic, the need for a strict quantitative estimation of the EEG has led to a regular question about its statistical nature. As early as in the fifties Norbert Wiener had proposed that the EEG should be considered as a sto- chastic signal by analogy with the output characteristics of any complex system [3].

Nowadays the EEG is considered as an additive sum of the stationary random function obtained at the output of the linear filter, at the input of which the "white noise" entered, and the harmonic functions [4 - 6].

The paradoxical method, developed by physicists for signal extraction against the high-noise background, has come to be known as the stochastic resonance (SR) effect $[7,8]$. One of the basic features of the method is its capability of separating low-frequency components [7, 8]. So, it appeared natural that by applying the SR method to the patient's EEG implementation one could try to separate low frequencies, which are pathological for the wakeful adult. 
Fig. 1 shows the EEG implementation for the patient. The given implementation spectrum and the spectrum of the output signal of the stochastic resonator are presented in Fig. 2. Fig. 2,b shows the 0 to $5 \mathrm{~Hz}$ band in greater detail.

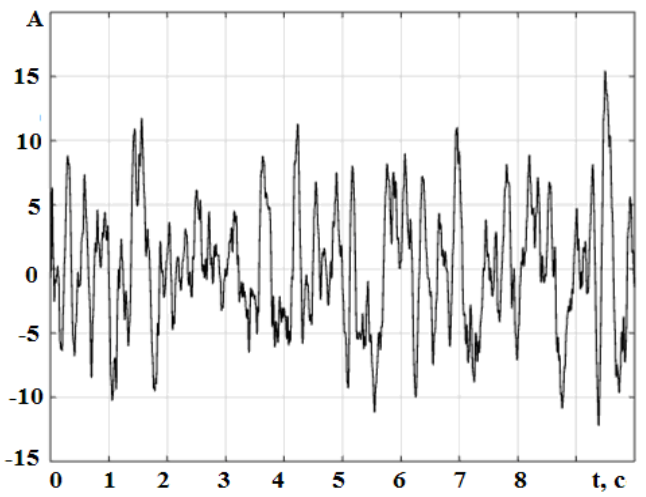

Fig. 1. EEG implementation for the patient
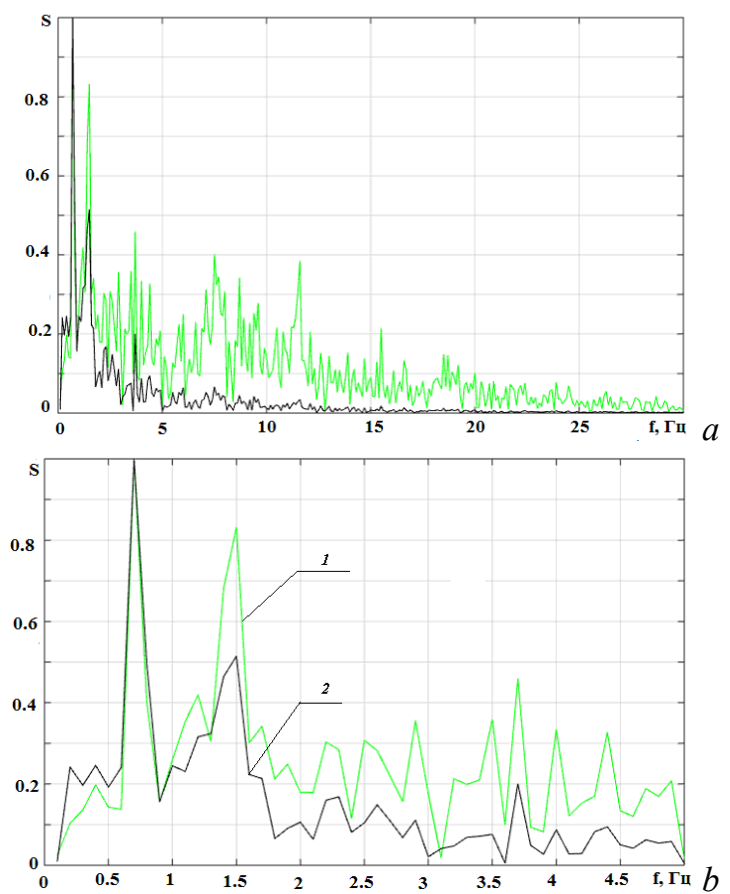

Fig. 2. The EEG implementation spectrum for the patient (green line-1) and the spectrum of the output signal from the stochastic resonator (black line-2)

From Fig. 2 it can be seen that there are two peaks in the low frequency region. These peaks are found at the frequencies $f=0.7$ and $1.5 \mathrm{~Hz}$. The given frequencies fall within the $\delta$-rhythm band. The $\theta$-rhythm band exhibits no clear cut peaks.

It appears of interest to compare the present results with the data of the other method, which also permits separation of the harmonic components from the additive mixture with the noise.

\section{METHOD OF EEG RHYTHM SEPARATION BASED ON THE TREATMENT OF THE ACF}

The given method is based on the use of the differences in the ACFs contributed by the white noise and by the process composed of a discrete set of harmonic components (assumed here as the sum of EEG rhythms) [9].
With this method, it is possible to determine the power spectral density of the process cleared of the white noise.

Let us write down the EEG signal $\zeta(\mathrm{t})$ as a sum

$$
\varsigma(t)=\xi(t)+\eta(t)
$$

where $\xi(t)$ is the linear combination of the harmonic components; $\eta(t)$ is the noise component. Then the ACF of the total process will be defined as

$$
R_{\varsigma}(\tau)=R_{\xi}(\tau)+R_{\eta}(\tau)+R_{\xi \eta}(\tau)+R_{\eta \xi}(\tau),
$$

where $R_{\xi \eta}(\tau), R_{\eta \xi}(\tau)$ are the relative correlation process densities $\xi(t)$ and $\eta(t)$.

By neglecting the components $R_{\xi \eta}(\tau)$ and $R_{\eta \xi}(\tau)$, we obtain [7]

$$
R_{\varsigma}(\tau)=R_{\xi}(\tau)+R_{\eta}(\tau)
$$

where according to ref. [8], we have

$$
R_{\eta}(\tau)=\frac{W_{0} \sigma(\tau)}{2},
$$

$W_{0}$ is the white noise power, $\sigma(\tau)$ is the root-meansquare deviation.

Since the $R_{\eta}(\tau)$ value rapidly decreases with the increasing $\tau$, and hence, the noise ACF is found near zero, then, at sufficiently high $\tau$ values, the ACF of the process will be determined by the harmonic components of the $\xi(t)$ signal.

Fig. 3 shows the plotted ACF of the EEG implementation presented in Fig. 1.

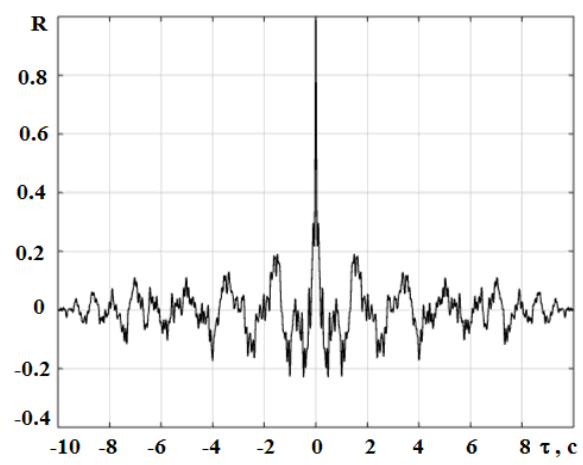

Fig. 3. ACF of the EEG implementation presented in Fig. 1

Using the Wiener-Khintchine theorem $[9,10]$ and taking the EEG fragment over a distance of 50 counts from the origin of coordinates, we find the spectral components of the EEG (Fig. 4). The spectrum in the range of 0 to $5 \mathrm{~Hz}$ is given in greater detail in Fig. 4,b.

Fig. 4 exhibits two peaks in the $\delta$-rhythm band, their frequencies being $f=0.7$ and $1.5 \mathrm{~Hz}$. The $\theta$-rhythm band shows no strongly pronounced peaks.

The comparison between the curves shown in Fig. 4 and Fig. 2 has shown good agreement of the peaks in the $\delta$-rhythm band. This result is the confirmation of the obtained numerical SR-based calculations. The low frequencies of the EEG are of vital importance in the diagnostics of nervous diseases; therefore, the present results may find wide application in medical practice. 

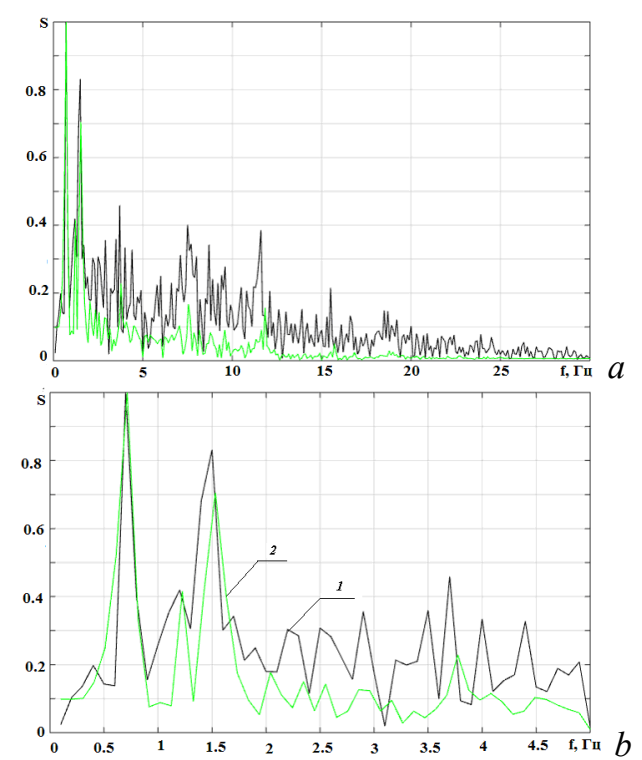

Fig. 4. EEG power spectral density (black curve-1)

and the EEG power spectral density resulting

from the processing of the ACF (green curve-2)

As can be seen from the above, the use of the SR effect in the EEG implementations will make it possible to carry out a higher-quality medical diagnosing and to detect pathological changes.

\section{CONCLUSIONS}

The EEG processing problem consists in detecting the harmonics (frequencies, rhythms) caused by the brain activity. This detection is carried out against the background of intense noises generated by the activity of neurons.

The pathological changes make themselves evident in the EEG by the occurrence of slow rhythms $\theta$ and $\delta$. Therefore, their detection is of vital importance in clinical practice.

The SR effect has made it possible to separate the low-frequency components, which fall within the $\delta$ rhythm band, and this is currently central in the neuropathology diagnostics.

For verification, the data obtained with the use of the SR effect have been compared with the results of the
EEG rhythm separation on the basis of the ACF processing. The comparison has shown their good agreement.

\section{REFERENCES}

1. L.P. Zenkov, M.F. Ronkin. Functional diagnostics of nervous diseases: Manual for Physicians. M.: "Meditsina publ.", 1991, 640 p. (In Russian).

2. L.R. Zenkov. Clinical electroencephalography (Epileptologyc elements included). Manual for Physicians. M.: "MEDpressinform publ.", 2004, 368 p.

3. N. Wiener. New chapters of cybernetics. Command, control and communications in animals and machines. M.: "Sovetskoye Radio publ.", 1963, 230 p.

4. N.V. Kiselyova, A.V. Medvedev, A.A. Frolov. Analysis of static characteristics of compound action potentials of the rat brain // Zhurnal Vysshej nervnoj deyatel'nosti. M.: "Nauka publ.", 1989, v. 39, issue. 4, p. 783-788.

5. O.I. Kharchenko. Application of the spectral method to stochastic filter analysis // Problems of Atomic Science and Technology. Series "Plasma Electronics and New Methods of Acceleration”. 2019, № 6, p. $128-133$.

6. O.I. Kharchenko, Yu.F. Lonin, A.G. Ponomarev. Frequency analysis of the stochastic filtering using transfer functions. Part i: sinusoidal input // Problems of Atomic Science and Technology. Series "Plasma Electronics and New Methods of Acceleration”. 2018, № 4, p. 249-251.

7. V.S. Anishchenko, A.B. Neiman, F. Moss, L. Schimansky-Geier. Stochastic resonance: noise-enhanced order // Uspekhi Fizicheskikh Nauk, Russian Academy of Sciences. 1999, 42(1)7-36, p. 7-34.

8. O. Kharchenko. Simulation of the Stochastic Resonance Effect in a Nonlinear Device // Global Journal of Researches in Engineering. 2015, v. 15, issue. 7, Version 1.0, p. 19-23.

9. Yu.I. Voloshchuk. Signals and processes in radio engineering: College Textbook. V.2. Kharkiv: "Kompaniya SMIT", 2003, 444 p.

10. S.I. Baskakov. Radio technical circuits and signals: Manual. M.: "Vysshaya Shkola publ.", 1983, 536 p.

Article received 27.05.2021

\section{ВЫДЕЛЕНИЕ НИЗКОЧАСТОТНЫХ СОСТАВЛЯЮЩИХ ЭЛЕКТРОЭНЦЕФАЛОГРАММ НА ОСНОВЕ ЭФФЕКТА СТОХАСТИЧЕСКОГО РЕЗОНАНСА}

\section{О.И. Харченко, Ю.Ф. Лонин, Л.П. Забродина, В.М. Карташов}

Приведен метод анализа электроэнцефалограмм (ЭЭГ) на основе эффекта стохастического резонанса. Численный расчет позволил выделить низкочастотные составляющие, которые попадают в полосу $\delta$-ритма, что является актуальным в диагностике нервных болезней, поскольку низкие частоты в ЭЭГ являются патологичными и свидетельствуют о заболевании. Для верификации полученных результатов был проведен сравнительный анализ численных расчетов на основе эффекта стохастического резонанса и расчетов на основе автокорреляционной функции, который показал их хорошее совпадение.

\section{ВИДІЛЕННЯ НИЗЬКОЧАСТОТНИХ СКЛАДОВИХ ЕЛЕКТРОЕНЦЕФАЛОГРАМ НА ОСНОВІ ЕФЕКТУ СТОХАСТИЧНОГО РЕЗОНАНСУ \\ О.І. Харченко, Ю.Ф. Лонін, Л.П. Забродіна, В.М. Карташов}

Наведено метод аналізу електроенцефалограм (ЕЕГ) на основі ефекту стохастичного резонансу. Чисельний розрахунок дозволив виділити низькочастотні складові, які потрапляють у смугу $\delta$-ритму, що $є$ актуальним у діагностиці нервових хвороб, оскільки низькі частоти в ЕЕГ є патологічними і свідчать про захворювання. Для верифікації отриманих результатів було проведено порівняльний аналіз численних розрахунків на основі ефекту стохастичного резонансу та розрахунків на основі автокореляційної функції, який показав їх гарний збіг. 